\title{
La vida no es una telenovela: \\ técnica y estética en el teatro de Eduardo Adrianzén
}

\section{Gail A. Bulman}

Syracuse University

Es cierto que la telenovela da muchas vueltas sobre lo mismo, pero no es menos cierto que la vida también. En una de ellas las verdades rondan, se alejan, se acercan de nuevo y tardan 100 capítulos o 15 años en concretarse; y las verdades en la vida, también. Aunque a muchos no les guste, cualquier vida, por más anodina que parezca, puede verse como una telenovela, porque siempre existen obstáculos, objetivos y resultados, buenos o malos. No solo eso: a los demás nos gusta enterarnos de estos avatares.

Eduardo Adrianzén (2001: 21)

Cuando hago teatro, trato más bien de olvidarme de todas las reglas, trato de jugar y trato de tontear el mayor tiempo que pueda antes de atacar la obra.

Eduardo Adrianzén, entrevistado por Geirola (2004: 171)

\section{RESUMEN}

Lo que sorprende en las obras teatrales de Eduardo Adrianzén no es siempre la temática, aunque, sin duda, los temas que este dramaturgo peruano selecciona nunca se alejan de las controversias religiosas, políticas y personales. No obstante, la manera original en que Adrianzén entreteje sus historias es lo que le permite indagar en los traumas más profundos de su nación y de la humanidad. En este trabajo se descifran algunas de las técnicas teatrales que Adrianzén emplea en una de sus obras más recientes, Respira, para revelar por qué esta y otras obras suyas logran agradar tanto a su público y siguen ganando premios, aun cuando presentan fuertes condenas de las instituciones religiosas, políticas y sociales e incluso cuando critican a los mismos receptores que forman el público que las aprecia. 


\section{PALABRAS CLAVE}

Eduardo Adrianzén, Perú, telenovela, violencia política, trauma, metateatro, comedia clásica, tragicomedia, consensus, habitus, íconos, fe.

\section{ABSTRACT}

What is surprising about the theatrical works of Eduardo Adrianzén is not always the subject, although, the topics that this Peruvian playwright selects are never far-removed from religious, political and personal controversies. However, the original way in which Adrianzén interweaves his stories is what allows him to examine the most profound traumas of his nation and of humanity. In this essay, we can decipher some of the theatrical techniques that Adrianzén uses in one of his most recent plays Respira, to reveal why this play as well as his other plays manage to greatly please his audience and continue to win awards even when they present such strong disapproval of religious, political and social institutions, and even when the recipients of his criticism are those who make up the audience that praises his works.

\section{KEY WORDS}

Eduardo Adrianzén, Peru, soap opera, political violence, trauma, metatheatre, classic comedy, tragic comedy, consensus, habitus, icons, faith.

En su estudio de la telenovela, el guionista y dramaturgo peruano Eduardo Adrianzén articula las similitudes entre la vida y las telenovelas, y postula que los seres humanos poseemos una curiosidad y necesidad de comunicarnos sobre las complicaciones de la vida. No obstante, la manera de comunicarnos sobre estos temas encuentra una forma distinta dependiendo del medio de comunicación. Adrianzén afirma que «la telenovela aventaja al libro y la radio porque no es necesario hacer un ejercicio de abstracción: los hechos suceden "en carne y hueso" ante nuestros ojos. Aventaja al cine y al teatro porque no es necesario salir de casa: entra a nuestra intimidad por una pequeña pantalla ubicada frente a la comodidad del sillón o la cama» (Adrianzén 2001: 21). Sentado frente a la pantalla del televisor, el espectador de telenovelas es testigo de los traumas de personajes cuya vida íntima se desarrolla y se enreda delante de sus ojos, pues «la esencia más profunda de la telenovela pertenece a la esfera privada, al sentimiento íntimo y a los secretos del corazón» (Adrianzén 2001: 55). 
Tal como en las telenovelas, en el teatro también los dramaturgos luchan por encontrar el equilibrio apropiado entre pintar los grandes problemas sociales de todos los tiempos y penetrar la esfera privada de unos personajes dotados de cualidades y deficiencias humanas, las cuales son comprensibles y temibles a la vez. No obstante, en el teatro hay que entrelazar contextos universales con los personales y completar historias íntimas iniciadas hace un momento dentro de un tiempo mucho más corto y compacto que las semanas en que las telenovelas desarrollan sus 6.500 páginas de escritura ${ }^{1}$. Aunque el tiempo del desarrollo sea distinto en el teatro y las telenovelas, las técnicas que se emplean en cada género para manipular al público y asegurar su interés comparten cierta sofisticación, aun cuando no son las mismas.

Adrianzén afirma que las telenovelas se desarrollan con una estructura algo fija y formulaica, pero, por otra parte, cuando él empieza a escribir una obra teatral trata de «olvidarse de las reglas». Por eso, en las obras teatrales de Adrianzén, lo que sorprende no es siempre la temática, aunque sin duda, los temas que selecciona nunca se alejan de las controversias religiosas, políticas o personales. La manera original en que Adrianzén entreteje sus historias teatrales es lo que le permite indagar en los traumas más profundos de su nación y de la humanidad. En este artículo se descifran algunas de las técnicas teatrales que Adrianzén emplea en uno de sus trabajos más recientes, Respira, para revelar por qué esta y otras de sus obras teatrales logran agradar tanto a su público y siguen ganando premios, aun cuando presentan fuertes condenas de las instituciones religiosas, políticas y sociales, y pese a que critican a los mismos receptores que forman el público que las aprecia.

Eduardo Adrianzén empezó su carrera artística antes de 1985, cuando representó un pequeño papel en la película La ciudad y los perros, basada en la novela famosa de Mario Vargas Llosa, bajo la dirección de Francisco J. Lombardi. Desde entonces, Adrianzén sigue dejando su marca innegable en la escena artística del Perú. Nacido en Lima, recibió el bachillerato en Derecho de la Universidad Nacional Mayor de San Marcos. Actualmente, trabaja activamente como guionista y productor de telenovelas y también como dramaturgo. Hasta el momento de la publicación de Respira, había

\footnotetext{
1 Adrianzén habla sobre el proceso de escribir y producir telenovelas: «En los orígenes, un solo autor bastaba para 60 capítulos de 15 minutos cada uno. En cambio, tratándose de una telenovela actual de, digamos, 180 capítulos de una hora a razón de unas 35-40 páginas cada uno, estamos hablando de un promedio de 6.500 páginas que deberán escribirse en unos nueve o diez meses. Semejante volumen de trabajo no debe ser asumido por una sola persona y, en el remoto caso de que aún suceda — que hay locos, los hay—, es imposible que salga bien» (Adrianzén 2001: 174).
} 
«realizado 35 ficciones en televisión, entre novelas y miniseries» (cubierta de Ponemos tu obra en escena); entre ellas, Carmín (1985), La Perricholi (1992), Los de arriba y los de abajo (1994-1995), Tribus de la calle (1996), Todo se compra, todo se vende (1997), Amor serrano (1998), Girasoles para Lucía (1999) y muchas otras².

La productividad teatral de Adrianzén no es menos impresionante que su trabajo como guionista de televisión. Entre sus obras publicadas, se encuentran El día de la Luna (en la antología Dramaturgia peruana contemporánea, publicada en Estados Unidos en 1999, y editada por Teatro Bellavista Ediciones en 2009), Cristo light (en el segundo número de la revista teatral Muestra, en 2000), La tercera edad de la juventud (en el segundo tomo de la antología Dramaturgia peruana contemporánea, 2001) además de Espinas, Azul resplandor, Demonios en la piel, Respira, entre otras. Sus obras contienen temas universales que las hacen siempre relevantes al mismo tiempo que tocan cuerdas muy íntimas en la psique de los peruanos. Muchas también se han puesto en escena: De repente, un beso (1995), El día de la Luna (1996 en Lima y 1998 en Bulgaria, dirigida por Ruth Escudero), Cristo light (1997), Tres amores postmodernos (1998), La tercera edad de la juventud (1999), El nido de las palomas (2000 y 2013), Espinas (2001), Azul resplandor (2005), Demonios en la piel (2007), Cuatro historias de cama (2008 en Lima y 2013 en Buenos Aires), Respira (2009) y Heraud, el corazón volador (en coautoría con Claudia Sacha, 2009), y Diecisiete camellos $(2010)^{3}$.

Escrita en 2008 y ganadora del Segundo Concurso de Dramaturgia Peruana de la Asociación Cultural Peruano Británica ese mismo año, Respira se estrenó un año después, bajo la dirección de Roberto Ángeles ${ }^{4}$. Con un

2 En 2013 se han presentado dos obras suyas en la televisión: Conversando con la Luna (un ciclo de 11 telenovelas cortas de contenido educativo que van a continuar en octubre de 2013) y Mi amor el Wachimán (una telenovela cómica-melodramática).

3 El éxito de Adrianzén como dramaturgo está creciendo cada año. El escritor admite: «Este año 2013 está resultando muy, muy movido, y felizmente bueno» (e-mail personal, agosto de 2013). Han reestrenado cinco obras suyas: Cristo light (por un grupo del Club de Teatro de Lima), La eternidad en sus ojos (en la AAA; la obra fue seleccionada para el Festival de la Municipalidad en noviembre de 2013 y se volverá a estrenar en febrero de 2014 en el Centro Cultural de España), El nido de las palomas (fue dirigida por Renato Fernández en el Teatro Mocha Graña en Barranco), El día de la Luna (en el Teatro Racional) y Espinas (en el Mocha Graña). Al mismo tiempo en que su fama en el Perú crece, sus obras empiezan a ser estrenadas con más frecuencia en el exterior. En 2013 muchas han sido montadas en otros países: Cuatro historias de cama en Buenos Aires, Azul resplandor en São Paulo, Respira en México D. F. (dirigida por la misma directora que la hizo en São Paulo en 2011, Carla Bauche).

4 El elenco incluyó a Leonardo Torres Vilar (Mario), Javier Valdés (Felipe, padre de Mario), Víctor Prada (padre Simón), Graciela Paola Grapa (la abuela Herlinda), Patricia de la Fuente (Pilar, madre de Mario), Javier Echevarría (Walter, amigo de Mario), Renzo Schuller (Jesús) y Sebastián Monteghirfo (Renato, hermano de Mario). Vi la obra durante su estreno en Lima. Las citas en este artículo vienen de Adrianzén 2009. 
elenco maravilloso y a pesar de su premio, la obra provocó una gran controversia, que causó que el Consejo Directivo del Centro Cultural Británico distribuyera a los espectadores la siguiente advertencia escrita cuando entraban en el teatro:

La obra teatral Respira contiene escenas que pueden ofender la sensibilidad de los creyentes católicos, así como la de los cristianos en general. La Asociación Cultural Peruano Británica ha decidido que se mantenga en escena, cumpliendo las condiciones preestablecidas en el concurso promovido por ella y dirimido por un jurado especializado e independiente (Quiroz Ávila 2012: 156).

No hay duda de que la obra incluye una condena del catolicismo, de las acciones de los sacerdotes y los practicantes, no solamente en el Perú sino en el mundo entero. Estos escándalos han agarrado fuerte al Perú, pero es todavía posible que las controversias católicas en el Perú no sean más chocantes que en otras partes del mundo ${ }^{5}$. Tanto el diálogo como las acciones del padre Simón, sacerdote pedófilo y avaro en la obra, parecerían exagerados si no fueran tan históricamente acertados. Tampoco hay mucha hipérbole en el comportamiento de Herlinda, abuela fanática de Walter, un niño exageradamente puro e inocente; pues todos conocemos a una Herlinda, una persona que se pega tan fiel y ciegamente a la doctrina católica aun cuando sea obvio que pueda hacerle daño personal y social.

Sin embargo, la reacción hacia la denuncia religiosa enmascara otras críticas dentro de la obra: una condena de la política peruana justo antes e incluso después de la horrorosa violencia política en el Perú de la década de 1980 y, más que nada, una crítica hacia los mismos peruanos que al fin y al cabo dejaron que aquella violencia se desarrollara de manera frenética, pues no se hizo nada para detener las atrocidades y ahora se tiene que vivir con la culpa frente a este hecho ${ }^{6}$.

Aunque su protagonista enfrenta a solas el peso de esa culpa, la obra logra escenificar el cargo psicológico de la nación entera frente al recuerdo de casi dos décadas de violencia incomprensible: una guerra civil que

5 Un artículo por Jonathan Friendly publicado en The New York Times en 1986 confirma que aún en la década de 1980 había muchos casos de sacerdotes católicos que fueron acusados de haber abusado sexualmente a jóvenes: se enteró de 40 casos de 1984 a 1986 en Estados Unidos. Hay otros documentos que prueban que «el abuso sexual por parte de los frailes de la provincia de San José de la Orden de los Capuchinos fue notado y documentado en reuniones desde 1932, el primer año en que empezaron a mantener récords de las reuniones» (Goodstein 2013). Desde aquella fecha se siguen revelando los crímenes de curas pedófilos en todas partes del mundo, incluyendo el Perú.

6 Adrianzén ha expresado: «Mi obra Respira nació de la culpa. Mi generación es una generación que carga muchos muertos» (Quispe 2009). 
robó la vida de casi 70 mil peruanos. Ileana Diéguez resume la guerra sucia en el Perú: «En el transcurso de 1980 al año 2000 la sociedad peruana quedó convertida en un violento escenario. La población civil, primero en el campo y luego en la capital, fue objeto del fuego cruzado entre los senderistas, las Fuerzas Armadas y los insurgentes del Movimiento Revolucionario Túpac Amaru» (Diéguez 2008: 33). Carlos Vargas Salgado también nos recuerda la magnitud de las atrocidades: «los hechos violentos que azotaron a la población peruana desde 1980 costaron la vida de alrededor de 70 mil personas y provocaron una incalculable pérdida económica, además de las secuelas de un trauma social generalizado, evidentes incluso en la actualidad» (Vargas Salgado 2012: 121). Vargas Salgado también enfatiza el papel importante y controversial de la Policía y del Ejército peruano en el conflicto: lo que se empezó como una batalla entre grupos de «terroristas» se convirtió en una guerra intensificada y prolongada por la Policía, el Ejército y grupos de ciudadanos que formaban «comités de autodefensa» ${ }^{7}$.

Respira encuadra todos estos temas, perspectivas y condenas dentro de una estructura enredada y complicada: entreteje procedimientos del teatro clásico al lado de elementos increíblemente innovadores; incorpora rasgos tradicionales de la comedia y la tragedia, juegos metateatrales muy adeptos, retrospectivas que intercalan el pasado con el presente, un manejo vertiginoso de movimiento yuxtapuesto con una manipulación de objetos estáticos y un control sobre los íconos culturales que abre espacios brechtianos que esfuerzan al público a reflexionar sobre su propio papel en la creación, repetición y aceptación de las maldades institucionales y las violencias que brindan.

7 Carlos Vargas Salgado resume las múltiples facciones que participaron y las varias perspectivas sobre la guerra sucia en el Perú:

El Partido Comunista Peruano (PCP) liderado por el profesor universitario Abimael Guzmán en la ciudad de Huamanga, Ayacucho - facción a la que empieza a llamarse Sendero Luminoso (SL) por una azarosa interpretación de la Policía peruana- decide iniciar una guerra popular contra el Estado oficial del Perú a través de acciones de amenaza al orden democrático establecido. Esa guerra, llamada revolucionaria por Guzmán y sus seguidores, y descrita casi desde sus inicios por parte del Estado como acciones terroristas, es respondida casi de inmediato por las fuerzas del orden del Estado peruano, las Fuerzas Policiales, primero, y las Fuerzas Armadas (Ejército), después de diciembre de 1982. Un tiempo después, en 1984, un segundo grupo insurgente armado, el Movimiento Revolucionario Túpac Amaru, interviene en la escena nacional sin vínculo alguno con el Partido Comunista del Perú-Sendero Luminoso (PCP-SL), y tiene como objetivo organizar una guerrilla contra el Estado peruano. También a partir de 1984, los llamados comités de autodefensa en las zonas campesinas afectadas tuvieron intervenciones armadas, aunque aliados desde el inicio al Estado peruano (Vargas Salgado 2012: 121).

Ver también Fumerton y Remijnse 2004 para saber más sobre los comités de autodefensa. 
Con mucha destreza, Adrianzén logra enraizar su crítica en un lenguaje y unas estructuras dramáticas que permiten que el público vea lo absurdo y peligroso de los sistemas que ha creado y que empiece a enfrentar su propia responsabilidad en los traumas nacionales y universales. En Respira los grandes problemas sociales de todos los tiempos se entrecruzan con las catástrofes provocadas por eventos específicamente peruanos que se llevaron a cabo en una época particular. Y todos estos temas universales y nacionales, amplios y específicos a la vez, se evocan a través de la representación de su profundo impacto en la esfera íntima de una familia peruana ficcional. En la obra se ve cómo los traumas individuales de Mario y su hermano Renato se abren para revelar los traumas compartidos por muchos peruanos. Una vez que son revelados como traumas colectivos, el dramaturgo empieza a desmantelar las posibles maneras de actuar frente a ellos.

Respira se abre con Mario adulto petrificado en el borde de una piscina recordando un momento cuando tenía diez años y casi se ahogó. Ese recuerdo le provoca a Mario adulto reflexionar sobre su apatía frente a la vida y le inspira a recordar las tensiones familiares y los abusos sexuales del padre Simón en la escuela católica a la cual su madre le había obligado a asistir. Por otra parte, en la obra también se vislumbran los traumas políticos a través del personaje de Renato, hermano mayor de Mario. Desilusionado en su juventud por la indiferencia y egoísmo de sus padres frente a un pequeño niño mendigo que se acercó a la mesa de su familia en un restaurante de lujo, Renato se convirtió en revolucionario y buscó cualquier causa que no fuera la de sus padres. Renato recuerda aquel momento:

Ya había llegado la sopa wantán, la gallina tipakay, el chaufa, el kamlu, el chancho al ajo. Yo miraba fascinado la mesa repleta de comida, y papá era feliz al verme devorando tantas delicias. De pronto, se acercó a la mesa un niño exactamente de mi edad. No estaba sucio ni parecía lumpen. Solo era pobre. Llevaba en los ojos la mirada del hambre. Una herida en las pupilas imposible de curar en mil años. [...] Mamá se incomodó. [...] Papá le dijo «no, gracias, chiquito» y le ofreció una gaseosa. [...] Me quedé inmóvil. Nadie habló el resto de la cena. [...] Y yo jamás olvidé sus ojos carcomidos por el hambre (Adrianzén 2009: 45).

Decepcionado por la injusticia que ve no solo en la falta de acción y la actitud de sus padres, sino en la apatía de todos sus compatriotas, decide alejarse del partido político preferido de su papá y juntarse a la causa revolucionaria. Carlos Iván Degregori confirma que muchos peruanos jóvenes de la época sentían cierta atracción hacia los grupos revolucionarios, 
porque la identidad tradicional de sus padres no se ajustaba a la imagen que ellos tenían de su propia identidad. El terrorismo les ofreció el mito de la movilidad social y encajaba bien en sus ideas de la aventura juvenil (Degregori 1999). Renato es ese joven peruano estereotípico de aquella época que andaba buscando la posibilidad de llenar el vacío al juntarse a una revolución desacertada.

Aunque sea un tema serio y realista, la crítica política se ilumina con humor en Respira. En una escena se enumera la lista larga de partidos políticos posibles en el Perú de finales de los años 70 y el autor se burla de ellos a través de los comentarios de los personajes, pues se tiene la idea de que no importaba a cuál de estos se asociaran, ya que todos eran iguales. No obstante, el humor se termina cuando se aprende que Renato murió asesinado por su selección (Adrianzén 2009: 30-33). Y aunque Mario no se muera físicamente, las angustias psicológicas que enfrenta muestran el impacto muy serio de la situación.

Las historias paralelas de estos hermanos se presentan dentro de una estructura dramática que puede asemejar las buenas obras teatrales clásicas al mostrarnos que el individuo siempre se encuentra conectado a múltiples círculos sociales -empezando con su familia-, y que los traumas y las acciones personales siempre revelan la complejidad de las estructuras sociales e implican a la sociedad entera. De acuerdo con Timothy Reiss: «La cultura griega nos ha enseñado que el individuo está enlazado en una red de conexiones, desde lo familiar a lo cósmico; pues ser humano indica estar presente para los demás, existir en redes de significación colectivas y comunales» ${ }^{8}$. Igual en Respira: aunque tanto Mario como Renato están marcados por traumas personales, los traumas tienen sus raíces en la familia y en la sociedad entera (en los escándalos católicos y las equivocaciones políticas), y todos están afectados por estos.

Si bien la estructura de Respira oscila entre la de una obra teatral clásica y una buena telenovela, lo más notable es que la forma de la obra es la misma encarnación de lo que es un trauma. De acuerdo con las ideas de Ann Rothe sobre el trauma y Diana Taylor sobre la performance, Respira se convierte en un laboratorio dentro del cual se puede examinar la formulación del trauma y su transferencia del contexto individual al colectivo. Irónicamente, la fragmentación de Respira sirve como técnica que unifica la obra dramática y temáticamente. A través de sus retrospectivas y elementos metateatrales, la obra entreteje el pasado y el presente personal de sus protagonistas con el pasado y el presente nacional. El trauma de Mario

8 Citado en Felski 2008: 20-21. Todas las traducciones son mías. 
niño, el momento cuando casi se ahogó, explica las inseguridades y la falta de poder comprometerse del Mario adulto. De la misma forma, el enojo que experimentó Renato niño frente a la indiferencia de sus padres a las injusticias sociales le provocó comprometerse políticamente sin pensar en las consecuencias trágicas. Yuxtaponer el autoanálisis de ambos niños con sus confesiones a los otros personajes y al público abre momentos humorísticos en la obra que le permiten al público relajarse, al mismo tiempo que se subraya la complicidad entre todos en haber creado y sostenido los vicios institucionales. Así, la obra revela, según las teorías de Marvin Carlson, que «uno de los universales de la performance es su dependencia de los fantasmas que nos persiguen a todos» (Carlson 2001: 1).

Los fantasmas que Respira encarna son trágicos: no obstante, el humor enriquece la obra y facilita su recepción. A nivel lingüístico y en el juego metateatral el humor destaca las incongruencias en la vida, como bien había señalado Henri Bergson. Con mucha frecuencia un personaje expresa algo e inmediatamente otro personaje le contradice. Por ejemplo, cuando su madre expresa al público: «Siempre, de una u otra forma, Renato demuestra que es más hábil y más fuerte. Por suerte Mario no se da cuenta», Mario le da cara a este mismo público para revelar que sí se da cuenta: «Desde que nací, ya sé que Renato es más hábil y más fuerte» (Adrianzén 2009: 27). Las contradicciones muestran la ironía de las situaciones en las que los personajes se encuentran y nos hacen dudar de la honestidad detrás de las estructuras sociales más íntimas y esenciales a la vida. Enfatiza también que nunca estamos verdaderamente libres y bajo nuestro propio control: de hecho, el ser humano es siempre un títere controlado por otras fuerzas ${ }^{9}$. En Respira, esto se ve en varios momentos, pero cuando nos damos cuenta de que aún Cristo en la obra no puede controlar su propia imagen, eso sí desestabiliza al público y no hay más remedio que reírse de lo absurdo de la vida:

Luz sobre Mario y Cristo mirando un póster con la imagen de Jesús.

CRISTO. Y este, ¿quién es?

MARIO. Se supone que eres tú.

CRISTO. Todos se han propuesto fregarme la reputación. Parece una chica peluda: castaño casi rubio, naricita respingona, barba recortadísima y un peinadete que ni la Magdalena cuando se lavaba el pelo. Guapa mujer, valiente, aguerrida. Debería estar acá (Adrianzén 2009: 58).

9 Esta idea del hombre como títere o string puppet viene de Henri Bergson (en Bergson 1998: 25-34). 
Cuando Cristo ve su imagen en el póster, no se reconoce. Esta revelación lo enoja y lo inspira a pegarse al papel que él mismo quiere enfatizar: el de revolucionario. Dentro de este personaje universal se encarna la conexión entre la religión y la política, y se revela que las causas y las preocupaciones individuales de Mario y Renato son paralelas a las de Cristo. De esta forma, Adrianzén muestra técnicamente que lo individual es universal y viceversa.

Las tensiones que se establecen en esta tragicomedia autoproclamada le ofrecen al público la oportunidad de cuestionar las acciones y la incapacidad de actuar de estos héroes cuasi trágicos al mismo tiempo que le inspiran a ubicarse a sí mismo dentro de la gran tragedia que es la vida. Aprovechándose de muchas de las técnicas de la comedia clásica — que son, según David Hirst, una risa no destructiva, placeres modestos, una crisis fingida, un final feliz inesperado y la creación de una intriga cómica-, Respira facilita que «el público experimente el placer estético de participar sin tener que experimentar las consecuencias totales implicadas por la catársis trágica» (Felski 2008: 5). Mario no es el héroe trágico típico: su actitud autocrítica y sarcástica hacia las debilidades que él mismo nos revela hace que el público le tenga cariño, y nos permite reírnos a su lado frente a los multiples miedos, debilidades y a la pasividad que posee; así, Adrianzén crea un espacio seguro donde su público puede dar cara a sus propias inseguridades y dudas. La capacidad de Mario de burlarse de sí mismo como reacción a su letargo le ofrece mucho alivio a un público lleno de culpa frente a su propia pasividad.

El hecho de que en cada momento de tensión Mario se quede estático en el borde de la piscina proporciona un tipo de repetición cómica teorizada por Bergson; no obstante, el elemento trágico emerge porque Mario quiere entender el origen de su trauma y superarlo. Mario pregunta: « $i E s$ que en ninguna parte encontraría las respuestas?» (Adrianzén 2009: 48). Le confiesa al público:

MARIO. Escuché esa conversación detrás de una puerta. No quise decir nada. Papá, ¿por qué nunca hablamos de lo que pasó?

FELIPE. No quiero hablar.

MARIO. Pero yo sí, papá. Yo quería y tú siempre cambiabas de tema. [...] Yo solo quería escuchar la verdad.

FELIPE. ¿Para qué? La verdad es sobrevalorada. No sirve, te hace infeliz. [...]

MARIO. No. Quiero saber por qué no puedo sumergirme.

FELIPE. Ah. Debe ser tu trauma zonzo de la piscina. 
MARIO. No, papá. Es bastante más que eso. Y tú tendrías que entenderlo mejor que nadie (Adrianzén 2009: 63-64).

Petrificado y estático en el borde de la piscina, Mario se da cuenta de que su padre también está paralizado por el trauma, y que ninguno de los dos puede adelantarse porque quedan atrapados por instituciones que encarnan la misma violencia que quieren evitar. Mario admite: «En cuanto a mi vida [...] se resume a evadir» (Adrianzén 2009: 74). A lo largo de su viaje psicológico, empieza a reconocer el gran papel de esas instituciones en su trauma, pues su estancamiento frente a la piscina es una señal de la completa extensión de su trauma y Mario se da cuenta de que tanto su padre como la sociedad entera están igual de traumatizados. Al no encontrar respuestas dentro de la familia, espera más respuestas del Cristo que conoce, pero pronto advierte que este también es ilusión. Marcado por una inocencia cómica, el viaje de Mario es trágico en el sentido clásico: aunque reconozca las causas institucionales de su trauma, se da cuenta de que debe resolverlo personalmente. Pues, al fin y al cabo: «La tragedia se define por negar soluciones claras y juicios absolutos, porque la tragedia demuestra que el conflicto reside dentro del hombre» (Felski 2008: 7).

Parte del humor de esta tragicomedia reside en crear un paralelismo entre la vida de Mario y Renato y la del Cristo personaje, pues estos hermanos (y todos) sufren (sufrimos) como Cristo sufrió. Cristo, el personaje, también posee conflictos internos; se baja del crucifijo para ofrecer, al público y a Mario, su propia lectura de la situación. Su bajada provoca risa y al mismo tiempo postula una interpretación colectiva del trauma. El Cristo colgado en la cruz en Respira es testigo de las acciones abusivas del padre Simón hacia los niños. Nosotros también sabíamos lo que estaba pasando. Sin embargo, este Cristo muestra su lado egoísta, enfocándose en sí mismo y destacando el hecho de que lo hayamos enjaulado en imágenes equivocadas y a veces peligrosas. Lo toma como un ataque personal. Enfrentar el egoísmo de «Cristo» provoca risa, porque choca contra nuestras creencias. Sin embargo, este Cristo egoísta también impulsa a los receptores a reflexionar sobre su propio egoísmo, al mismo tiempo que les revela el impacto, a veces violento, de los símbolos que hemos inventado.

Al jugar con los símbolos culturales y al yuxtaponer los íconos estáticos que hemos creado y en los cuales nos apoyamos con el movimiento frenético de este Cristo vivo, revolucionario, sarcástico, desilusionado, amargo y, por encima de todo, humorístico, Respira juega con lo que Juan Villegas postula es la base de datos culturales que compartimos como sociedad. La obra se apoya en el conocimiento comunitario con respecto a la religión y sus símbolos artísticos y representativos (por ejemplo, el crucifijo, 
la hostia, los curas, los himnos y todo lo que ellos significan). Villegas nos recuerda que «El practicante de una cultura sabe qué gestualidad, qué imágenes, corresponden a qué prácticas culturales», pero descifrar la significación de toda práctica cultural requiere lo que él denomina consensus. Villegas sigue: «Desde esta perspectiva, el término consensus llega a ser indispensable al entendimiento de la cultura como práctica social» (Villegas 2000: 43). Además de consensus, Villegas también determina que como practicantes culturales nos apoyamos en habitus, lo que Bourdieu define como «el proceso por medio del cual lo social se internaliza y logra que las estructuras objetivas concuerden con las subjetivas» (Villegas 2000: 43 ${ }^{10}$. A través del consensus y del habitus, una sociedad llega a un acuerdo tácito y colectivo sobre el significado y la relevancia de sus símbolos culturales, y determina qué signos llegan a ser importantes.

Adrianzén juega muy bien con las nociones de consensus y habitus, al iluminar las imágenes culturales que se aceptan implícitamente —la imagen de Cristo, los himnos sagrados y los santos del discurso religioso, y los mismos partidos políticos que formamos- y luego al burlarse de estas imágenes culturales y destruirlas frente a los ojos de sus receptores. Desmantela la construcción de estos símbolos al mismo tiempo que provoca un fuerte cuestionamiento de su valor verídico. Hay momentos en Respira que le provocan al público cuestionar: ¿de veras creemos en esto? ¿Realmente nos apoyamos en esto? Hay muchos ejemplos de ello en la obra: cuando el padre Simón pide a Walter, Mario y sus invitados que canten los himnos sagrados durante la ceremonia de la eucaristía, Cristo pregunta: «QQuién michi compone estas canciones tan tontas?» (Adrianzén 2009: 65). Aceptamos que estos mismos himnos vacíos sirven de respuestas a las cuestiones y temas más profundos de la vida. De igual manera, cuando Mario interroga a su amigo Walter sobre el significado de los versos, este le contesta: «Así es la canción» (Adrianzén 2009: 39). Estos metacomentarios hacen vislumbrar nuestra ignorancia y apatía frente a los signos culturales autoimpuestos: no sabemos ni cómo ni cuándo se iniciaron ni qué significado tienen. No obstante, los aceptamos sin reserva y nos apoyamos en ellos. Como sociedad, nos hemos puesto de acuerdo en crear y aceptar las instituciones y símbolos culturales (consensus) y hemos internalizado su ideología y su estructura como parte relevante de nuestro sistema de creencias (habitus).

10Villegas afirma: «La misma idea con un pequeño matiz de diferencia es conceptualizada por Bourdieu, quien propone el concepto de habitus, al que caracteriza como el proceso por medio del cual lo social se internaliza y logra que las estructuras objetivas concuerden con las subjetivas» (Villegas 2000: 43). 
Los himnos sagrados, los íconos del Cristo que sufre, las pinturas de los mártires, e incluso el discurso de los partidos políticos y las acciones oficiales de la Policía y los Ejércitos, nos dan «consuelo» aun cuando estén llenos de contradicciones y una violencia latente que la sociedad entera imita. Esto se revela tanto en el Perú de los años 70 y 80 como en todas las sociedades que se adhieren ciegamente a valores políticos o religiosos sin examinarlos. Con mucha frecuencia, estos valores nos hacen invocar violencia política en el nombre de la Santa Palabra de Dios o de un gobierno mal pensado. Prueba de esto en la obra es cuando Mario y Walter hablan de la tortura del cantante Víctor Jara, y la aceptan y la comparan con el destino de los mártires religiosos:

WALTER. A mí, mi abuelita Herlinda me contó de Santa Águeda. Le quitaron toda la ropa, la amarraron a una piedra y le cortaron los senos. Por eso ella es mártir.

MARIO. ¿Le cortaron las tetas?

WALTER. ¡Shht, no se dicen malas palabras! Y a San Lorenzo, lo asaron vivo en una parrilla; $y$ a Santa Bárbara, la engancharon con garfios a una rueda; y a Santa Eulalia, le cortaron todito su cuerpo con hachas calientes, pero de su boca salió el Espíritu Santo en forma de paloma. ¡Ah! Y también le clavaron garfios. Eso es peor que el cantante que dices (Adrianzén 2009: 35).

Si el mismo discurso religioso propone como modelo este tipo de violencia, ¿por qué nos sorprende que haya violencia irracional en nuestro mundo real?

Al yuxtaponer la imagen aceptada e inmóvil de Cristo con este Cristo, personaje dinámico de carne y hueso quien comenta sobre las contradicciones inherentes en las representaciones de él, le muestra al público la preponderancia y la influencia de las imágenes culturales, al mismo tiempo que interroga las percepciones del público sobre la aceptación de estas imágenes. Los metacomentarios en la obra exponen lo absurdo de los sistemas culturales que hemos creado y nos hacen cuestionar hasta qué punto debemos seguir apoyándonos en ellos.

Por eso, el Cristo vivo que se postula como un revolucionario fracasado y enojado se presenta en movimiento para mostrarle al público que hay otras posibilidades para enfrentar los traumas colectivos. Como primer paso, hay que aprender a leer bien los símbolos culturales e interpretarlos de otra forma. Muchos tienden a buscar lo que quieren y necesitan en los símbolos culturales. Por ejemplo, la lectura de la abuela Herlinda del INRI en la parte arriba del crucifijo subraya su racismo. Para ella: «ilNRI significa "perdono a todos, menos a los indios"!» (Adrianzén 2009: 47). Pero cuando 
Mario niño no encuentra las respuestas que busca en los símbolos establecidos, Cristo le recomienda que lea de verdad. Cristo le dice: «No te hagas el inocente. Basta con que leas los panfletos que tu hermano esconde debajo de su cama. Pero ya te dije que si no lees...» (Adrianzén 2009: 66). Cristo le sugiere a Mario que empiece a interpretar y analizar los símbolos, en vez de aceptar su significado vacío. Este Cristo en movimiento se quita los clavos para presentarle a Mario la posibilidad de otras lecturas y otros caminos.

En la obra, la yuxtaposición del movimiento de un Cristo cuya imagen es culturalmente estática con el Mario paralizado y traumatizado se mezcla con una variedad de técnicas dramáticas para exponer estos mensajes complejos que nos tocan individual y colectivamente. A pesar de su mensaje aparentemente blasfemo, Respira es, más que nada, un viaje muy espiritual que nos llama a reflexionar y a leer con lente crítico el mundo que nos rodea. Se trata de la fe: fe en uno mismo, fe en los demás, fe en la humanidad y en nuestro destino común. Desde el principio de la obra, Adrianzén establece las tensiones y contradicciones dentro de los macromundos y entre ellos. El agua es el enfoque de la angustia de Mario, pues todos tenemos nuestras obsesiones. Incluso el agua puede señalar contradicciones en su misma esencia: el agua puede limpiar, purificar, alimentar y sostener o puede destruir civilizaciones enteras. Con una afirmación casi bíblica, Mario confirma: «Todo, absolutamente todo, es agua», y nos recuerda que el agua es la esencia de la vida. Sin embargo, aunque necesitemos el agua para vivir, el agua también nos puede ahogar, como Mario descubre. De igual manera, los sistemas sociales que construimos pueden sostenernos o pueden causar nuestra ruina. Hace falta reflexionar bien sobre ellos y leer las señales. Si no las leemos críticamente, pueden controlarnos y producir efectos negativos que perdurarán.

Llena de temas difíciles, divisorios y controvertidos, irónicamente esta tragicomedia nos regala una perspectiva casi optimista y llena de esperanza para enfrentar todas las dudas y los traumas que se nos presentan en la vida. De este modo, Respira nos anima a hacer exactamente esto: respirar de manera pausada y profunda, llenar de aire sano los pulmones y afrontar nuestros demonios. Con una reflexión enredada pero muy contemplativa sobre nuestro lugar en el mundo, Eduardo Adrianzén nos anima a establecer un equilibrio entre una vista crítica y la paz interna necesaria para sumergirnos en el mundo, nuestro mundo, con la meta de mejorarlo cuando y como podamos. 


\section{REFERENCIAS BIBLIOGRÁFICAS}

ADRIANZÉN, Eduardo (2001). Telenovelas. Cómo son y cómo se escriben. Lima: Fondo Editorial de la Pontificia Universidad Católica del Perú, 2001.

(2009). Respira. Ponemos tu obra en escena: Respira. Fantasía. El duende. Segundo Concurso de Dramaturgia Peruana 2008. Lima: Asociación Cultural Peruano Británica.

BERGSON, Henri (1998). «The comic in situations». En George W. Brandt (editor). Modern Theories of Drama: A Selection of Writings on Drama and Theatre, 1840-1990. Oxford: Clarendon Press.

CARLSON, Marvin (2001). The Haunted Stage: The Theatre as Memory Machine. Ann Arbor: University of Michigan Press.

DEGREGORI, Carlos Iván (1999). «Reaping the whirlwind: the rondas campesinas and the defeat of Sendero Luminoso in Ayacucho». En Kees Koonings y Dirk Kruijt (editores). Societies of Fear: The Legacy of Civil War. Violence and Terror in Latin America. Londres y Nueva York: Zed Books.

DE MARÍA, César (2009). «Dramaturgos del Perú: Eduardo Adrianzén». Consultado el 15 de abril de 2013 de http://autores-dramaturgosdelperu. blogspot.com/2009/09/eduardo-adrianzen.html

DIÉGUEZ, lleana (2008). «Prácticas escénicas y políticas en Latinoamérica: escenarios liminales peruanos». En Latin American Theatre Review, vol. 41, nro. 2, pp. 29-47.

FELSKI, Rita (editora) (2008). Rethinking Tragedy. Baltimore: The Johns Hopkins University Press.

FRIENDLY, Jonathan (1986). «Roman Catholic Church Discusses abuse of children by priests». Consultado el 15 de junio de 2013 de http://www. nytimes.com/1986/05/04/us/roman-catholic-church-discusses-abuseof-children-by-priests.html?ref=romancatholicchurchsexabusecases

FUMERTON, Mario y REMIJNSE, Simona (2004). «Civil defence forces: Peru's Comités de Auto-defensa Civil and Guatemala's Patrullas de Autodefensa Civil in comparative perspective. En Kees Koonings y Dirk Kruijt (editores). Armed actors: Organised violence and State failure in Latin America. Londres y Nueva York: Zed Books.

GEIROLA, Gustavo (2004, abril). «Con Eduardo Adrianzén: de la telenovela al teatro en el Perú del siglo XXl». En Gestos, nro. 37, pp. 167-177.

GOODSTEIN, Laurie (2013). «Audit finds sexual abuse was topic decades ago». Consultado el 15 de abril de 2013 de http://www.nytimes. com/2013/06/19/us/audit-finds-sex-abuse-was-topic-decades-ago.ht $\mathrm{ml}$ ?ref=romancatholicchurchsexabusecases 
QUIROZ ÁVILA, Rubén (2012). «Respira: La violencia política en el teatro peruano contemporaneo». Laurietz Seda (editora). Teatro contra el olvido. Lima: Fondo Editorial de la Universidad Cientifica del Sur.

QUISPE, Mirella (2009, 20 de abril). «Mi obra Respira nació de la culpa». Consultado el 18 de marzo de 2013 de http://www.larepublica.pe/20-042009/mi-obra-respira-nacio-de-la-culpa

ROTHE, Anne (2011). Popular Trauma Culture: Selling the Pain of Others in the Mass Media. Nueva Brunswick, Nueva Jersey y Londres: Rutgers University Press.

TAYLOR, Diana (2006). «DNA of performance: Political hauntology». En Doris Sommer (editora). Cultural Agency in the Americas. Durham y Londres: Duke University Press.

VARGAS SALGADO, Carlos (2012). «Para abrir la caja de Pandora: una aproximación al teatro peruano en el periodo del conflicto armado interno». Laurietz Seda (editora). Teatro contra el olvido. Lima: Fondo Editorial de la Universidad Cientifica del Sur.

VILLEGAS, Juan (2000). Para la interpretacion del teatro como construccion visual. Irvine, California: Ediciones de GESTOS. 